\title{
The EFfects OF the US Pivot TO ASIA ON EUROPEAN STRATEgIC COOPERATION
}

The current state of European strategic cooperation is optimistically described as "splintered" and pessimistically labeled as "nonexistent" by politicians and pundits alike. A potential retreat of the EU to staunch intergovernmentalism frustrates those who hoped Europe could reach its supranational potential to address global strategic challenges. The EU's Common Foreign and Security Policy (CFSP), its subsidiary Common Security and Defense Policy (CSDP), the European Defense Agency (EDA), and the European External Action Service (EEAS) were all designed to address modern strategic challenges, which can no longer be described as "state-versus-state." Terrorists, who operate globally and without national affiliation, pose a significant threat to national and regional security. Cyber warfare also presents a strategic challenge for those who shaped the original European institutions. The age of interstate conflict in Europe is over, but Europeans have struggled to adapt to a shifting security paradigm. Recently, spying scandals, misguided austerity, and loudening right-wing nationalism have further slowed down European strategic development.

Since the end of he Second World War, the United States has been the "white knight" of the European strategic community. From aiding Western Europe while under German oppression in consecutive world wars to smaller-scale operational assistance in the Western Balkans, the US has neutralized European strategic shortcomings. Moreover, the very framework of European strategy and European cooperation was molded by the US. From founding NATO as a deterrent to the rearmament of West Germany to pushing for European integration post-Cold War to stabilize Eastern Europe and nurturing the European monetary union to further integrate transatlantic trade relationships, the US has had a hand in the pocket of European affairs. ${ }^{1}$ However, that era may be coming to a close. The Obama administration has indicated that the US will adopt a "lead from behind" mentality in the 'European Neighborhood' as it rebalances its strategic objectives to the Pacific. ${ }^{2}$ Furthermore, the US has ordered the withdrawal of thousands of troops from Europe. ${ }^{3}$ The impact of the "pivot", the withdrawal of the troops, and what these buzzwords truly mean, will be the focus of this article.

Ostensibly, Europe has only two options in the wake of a potential US "abandonment": unite in the security vacuum left by America's withdrawal or fail to achieve European strategic cooperation and witness the potential collapse of the EU. However, both options are sensational and unlikely. This article will suggest a third, more probable outcome: a fledgling EU security nexus held afloat by continued American support. This article will begin by unpacking the perceived US abandonment of Europe, then will turn to an analysis of Europe's three options, and finish with a discussion of the future of Europe and the US. 


\section{Since the END OF the SECOND WORLD WAR, thE UNITED States has bEeN \\ THE "WHITE KNIGHT" OF tHE EUROPEAN \\ STRATEGIC COMMUNITY}

\section{The myth of “U.S. Abandonment”}

The US withdrawal of troops from Europe is more symbolically significant than operationally relevant. The nature of this withdrawal requires further dissection. To begin, it must be underscored that with the exception of a slight spike in the 1980s, the US has been withdrawing scores of troops from Europe consistently over the last half century (from 438,859 in 1957 to 98,087 in 2005). ${ }^{4}$ Second, the reduction of American soldiers is not equivalent to a reduced military presence in Europe. In fact, the US has increased its missiledefense capabilities in Europe over the past few years during this supposed "pivot." In February 2012, the US Navy announced that several guided-missile destroyers would be stationed at a base in Rota, Spain, as part of a new joint US-NATO European missile defense shield that is currently under construction. Additionally, existing US military units in Germany and Italy are being "modernized, reorganized and given newer equipment." 5 US military involvement in Europe is not disappearing, as reported in the press; it is being remodeled with continued investment in military technology upstaging troop withdrawals.

Further, despite decades of continued US troop withdrawal in Europe, transatlantic cooperation has rarely been called into question. US troops have effectively assisted European strategic actions in warring nations such as
Kosovo and Libya, despite their ever dwindling numbers. However, as British Defense Secretary John Nott warned in 1982 in the wake of US troop reductions from Europe during the Cold War, "It is well to remember that it is not only numbers, but the perception of change, that is important. Any reduction which was perceived to cast doubt on the strength of the American commitment to Europe would serve only to weaken deterrence." Although Europe is no longer under constant threat of a Soviet nuclear attack, the Secretary's warning is still relevant. The perception of a US abandonment of Europe is disturbing to Europeans unsure of how to cooperate in the absence of the US, and how to maintain security and defense dominance without US support. Even though US abandonment is a myth, there is a real threat that Europe will - in the words of Henry Kissinger-"analyze themselves into selffulfilling prophecies." ${ }^{\prime 7}$ Even the perception of a Europe without American support could be enough to destabilize the continent.

The US "pivot to Asia," a term coined by the Obama administration that has caused severe anxiety for European politicians and academics, may be no more than a public relations move by the administration in response to a rising China. China's military budget has eclipsed the $\$ 100$ billion mark (according to China's state media), allowing for developments in cyber technology and weapons capabilities, including a new fleet of nuclear-powered ballistic missile 


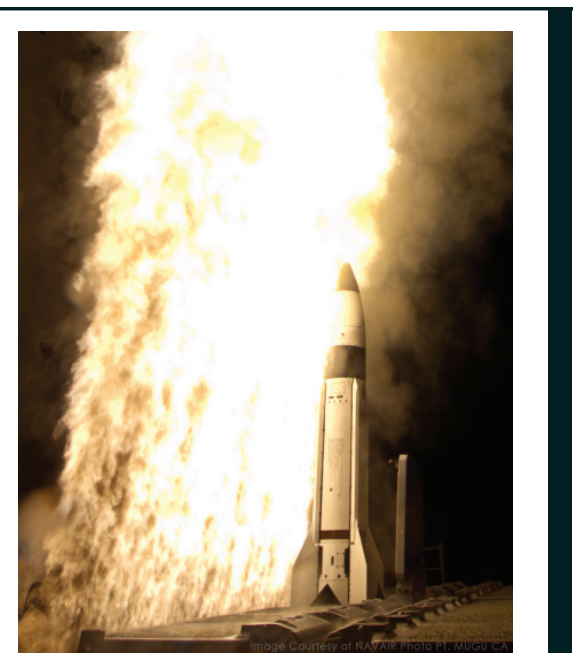

submarines. ${ }^{8}$ America's security hegemony in the Pacific is waning. The well-publicized "pivot" may be designed to reassure those anxious about a US decline and to send a strong message to China's new administration.

Recently, President Obama reassured Europe that "our relationship with our European allies and partners is the cornerstone of our engagement with the world, and a catalyst for global cooperation. In no other region does the United States have such a close alignment of values, interests, capabilities, and goals." Regardless, the message is clear: America no longer desires to mediate European strategic cooperation. In his testimony before the Senate Foreign Relations Committee, Georgetown University Professor Charles Kupchan said, "the drawdown of U.S. troop levels in Europe and the prospect of a 'pivot' to Asia should help convince Europeans that 'free-riding in perpetuity' is not an option." 10 Even if the "pivot" never develops beyond the hypothetical, the message to Europe is clear: "pool it or lose it." $" 1$

\section{EUROPE'S First OPtion: REnEWEd StRATEgIC COOPERATION}

Europe's first option is what many Europeans and Americans have been advocating for decades: the creation of a strategically united Europe, effective without constant supervision and intervention from the US. One short-term fix to US "abandonment" is an infusion of money by EU members. The EU possesses a sophisticated Defense Technological and Industrial Base (DTIB) and military potential second to none. ${ }^{12}$ However, their potential will never be realized at current defense spending levels. The EU spends an average of $1.67 \%$ of Gross Domestic Product (GDP) on defense, compared to $4.9 \%$ in the US, and the CFSP is woefully underfunded. ${ }^{13}$ Unfortunately, the prospect of member states increasing their defense budget is growing ever more unlikely. The Eurozone financial crisis is unrelenting, sapping funds from foreign security and defense to domestic crises. Further, a growing voice of right-wing nationalism prevents the member states to committing more money to a supranational network. ${ }^{14}$

Winston Churchill's quote is appropriate: "Gentlemen, we have run out of money. Now we have to think." 15 Without the infusion of money, the EU must think its way into cooperation, a far more durable, yet difficult, approach. However, this is unlikely for two reasons. The first is the debate between intergovernmentalism and supranationalism. Intergovernmentalists, representing the majority of EU heads of state today, believe that security and defense is fundamentally a national enterprise. A core principle of sovereignty is national security defense-a government is entrusted with ensuring the protection of their people and their people's interests. While the 
the US and Europe have a "Close

ALIGNMENT OF VALUES, INTERESTS,

CAPABILITIES, AND GOALS,"

\section{EUROPE IS AMERICA'S DEPUTY SHERIFF. WHY FIRE THE DEPUTY SHERIFF FOR A POTENTIALLY THREATENING PARTNER IN ASIA?}

definition of 'protection' and 'people's interests' is unclear, the reluctance of EU member states to relinquish this core principle in favor of supranational control may be reasonable. The French nuclear program is a useful example. The French boast an estimated 300 nuclear weapons, which they have publicized to the world. Although they, like supranationalists, ardently push for a strong EU CSDP and recommitted to NATO under President Sarkozy, the French refuse to share their weapons, believing national ownership is their right. ${ }^{16}$ In the security domain, individual state interests reign supreme.

The second reason greater cooperation is unlikely is because Article V of the NATO Treaty_-an attack on one is an attack on all'-thwarts EU member state participation in CSDP. ${ }^{17}$ This too is understandable - why spend the money and effort to build up defense capabilities if NATO guarantees national security? Critics argue that this 'lazy' mindset is potentially harmful to the future of Europeand they may be correct-but the mindset of the states is nevertheless rational.Because of the NATO/US safety net, European states are unlikely to increase defense spending and wholeheartedly push for strategic cooperation.

\section{EUROPE'S SECOND OPTION: COLLAPSE OF CFSP}

The prospect of a strategically united Europe is fading; intergovernmentalists might argue the very possibility was a pipe dream all along. Could the withdrawal of US troops be the knockout punch for supranational ambitions of EU cooperation? This is not likely for one simple reason: the US will not allow the collapse of the European project. From an economic perspective, abandonment is senseless. Since the Marshall Plan and several other post-war US investments, the US has spent a great deal of money both reconstructing and creating a Europe that suits American strategic interests. Further, in 2011, US direct investment in Europe accounted for more than half (or \$2.3 trillion) of their global sum. ${ }^{18}$ To withdraw completelywhile that investment is still yielding returnswould be a waste.

Moreover, Europe is-and will remain-America's closest ally for a variety of reasons. As Obama mentioned in the NATO Summit of 2010, the US and Europe have a "close alignment of values, interests, capabilities, and goals." ${ }^{19}$ Europe is America's deputy sheriff. Why fire the deputy sheriff for a potentially threatening partner in Asia? The positive returns of an exclusive relationship between the US and Asian partners would have to greatly outweigh the potential damages caused by an ineffective Europe. For the foreseeable future, it is unlikely that such a union will come into existence.

\section{A Third OPtion: Less GlORified SURVIVAL}




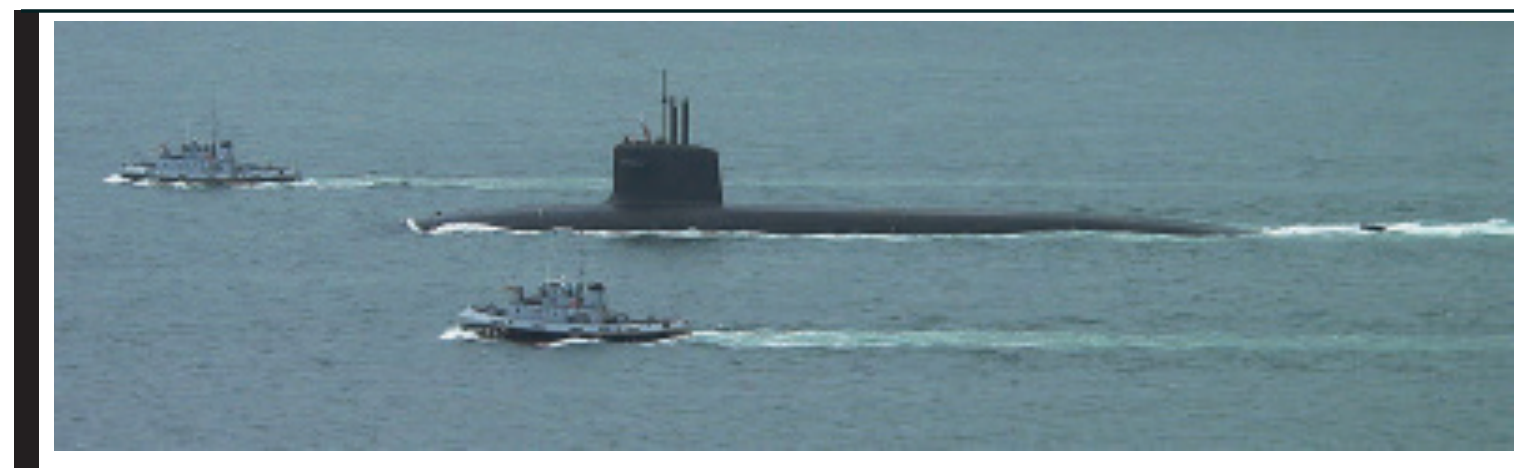

LE TERRIBLE (S 916) of the FRENCH NAVY. The FRENCH Maintain theiR OWN NUCLEAR DETERRENT, DEMONSTRATING THE RESERVATION OF EU MEMBER STATES TO RELINQUISH NATIONAL SECURITY TO SUPRANATIONAL CONTROL.

The third option for Europe, although the least salutary, is the disintegration of the EU security regime, leaving the entire continent reliant on US support. Europe will not increase strategic cooperation because of a lack of domestic will and money, a hesitancy to relinquish intergovernmentalist control in the domain of security and defense, and the security blanket of America, despite the so-called "pivot to Asia." Europe will not fail entirely because the US will not allow the devolvement of national strategic interests. Consequently, the likely scenario for the foreseeable future is a stalemate of inefficiency.

\section{FURTURE FOR EUROPE}

The future for European strategic cooperation will likely be limited. The EU will struggle to maintain any joint operational capabilities due to a lack of efficiency and cooperation, rather than equipment and personnel. The US will be forced to supply greater security assistance in order to preserve transatlantic interests. The future of European strategic cooperation will likely mirror the EU's response to the 2011 Libya crisis. In the Libya crisis, a cluster of member states (including the UK and France) proposed a joint action while others (including Denmark and Germany) opposed it. Despite EU fragmentation, the mission was carried out successfully and the US indeed "led from behind." ${ }^{20}$ Future cooperation may be in splintered form, but it will function via alliances of subgroups of member states with largely logistical help from the US.

Eventually, the financial crisis in Europe will recede. In a best case scenario, increasing GDPs and fewer domestic concerns will propel European countries to refocus on strategic cooperation. However, it is far more likely that Europe will continue to stumble along and be guided and protected by the US. The greatest fear for Europe and the world is not the collapse of the European security union (because of the NATO safety net), but rather the collapse of the economic union, which would have grave effects on the global economy. Europeans have shown a greater propensity to cooperate with one another in economic matters, but intergovernmentalist attitudes in the security sector will certainly strain intra-European relations.

\section{Future FOR THE U.S.}

The future for the US under option three is not bright. America is likely to grow even more overextended in the face of the "pivot" to Asia, which will likely correspond to greater economic and military involvement in the Pacific, and further maintenance of the European project. Growing nationalism and isolationism brewing at home threaten America's strategic agenda. According to a recent Rasmussen poll, "51 percent of voters surveyed said they wanted all US troops out of Europe, now. Only 29 percent 
NATIONALISM AND

ISOLATIONISM BREWING

AT HOME THREATEN

AMERICA'S STRATEGIC

$A G E N D A$,

CHAIRMAN OF THE JOINT CHIEFS OF

STAFF GEN MARTIN DEMPSEY DISCUSSES

REGIONAL SECURITY IN ASIA.

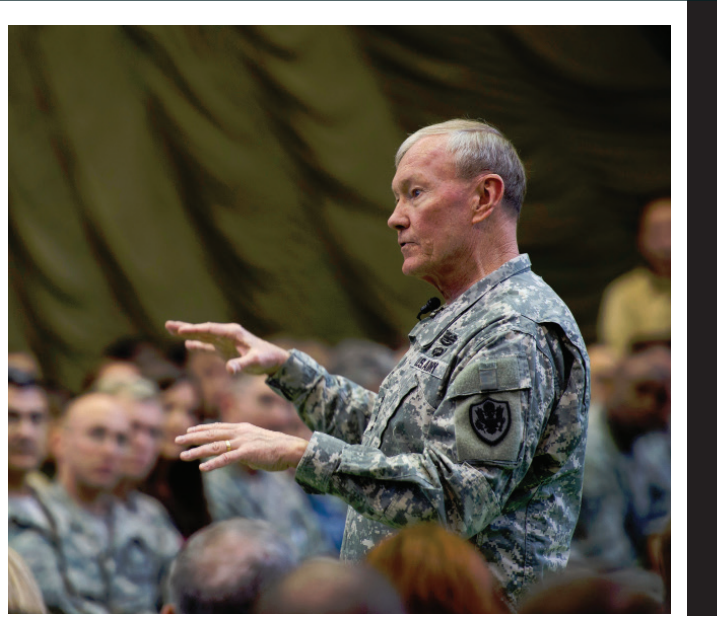

favored keeping the troops where they are." ${ }^{21} \mathrm{As}$ established earlier, US troop levels in Europe do not necessarily impact military presence on the continent. However, the isolationist attitude of an ever-growing majority of Americans is telling. Opinions, such as the following written by famous conservative Patrick J. Buchanan are widely shared: "As for Europe, the Red Army went home decades ago. Eastern Europe and the Baltic republics are free. As President Eisenhower urged JFK 50 years ago, we should bring U.S. troops home and let Europe man up to its own defense. No one threatens Europe today, and we could sell them all the missiles, tanks, ships, guns, and planes they need to defend themselves." ${ }^{22}$ Many Americans do not want to be involved strategically with Europe any longer, despite the benefits of a European partnership. It is unclear how the US government will be able to convey to the US public that a continued strategic relationship with Europe is essential, and if the American people will listen. Additionally, the US faces a shrinking defense budget. American historian Michael Auslin recently described the US budget crisis: "Pivot funding is in danger from sequestrationforced budget cuts resulting from larger budget politicking in Washington - that, if allowed to proceed, will cut another $\$ 500$ billion from a defense budget already reduced by $\$ 900$ billion since 2009." ${ }^{23}$ If the US can barely pay for "pivot funding", how will they pay for global strategic objectives, specifically in Europe? The rebuttal: "but, the US has survived thus far" is myopic. US strategic overextension under such budget stresses is unsustainable. Either a restructuring of the US budget, such as the reallocation of funds from Social Security to defense, an abandonment of a geostrategic program, greater European responsibility in NATO, or another cut will have to occur to keep the US fiscally afloat.

\section{CONCLUSION}

The US will not abandon European security in the wake of failed European security cooperation. They will maintain a robust military presence in Europe, honor NATO agreements, and continue to treat the $\mathrm{EU}$ as its key global ally. However, continued US military support may have grave consequences for the wellbeing of American domestic politics, and a failed CFSP may endanger the European Union as a whole.

\section{ACKNOWLEDGMENTS}

This article was conceived during my foreign study at the Institute of European Studies (IES) at Vrijie Universiteit Brussel, through a program coordinated by the University of Southern California. I am indebted to IES Professor Luis Simon and Doctoral Researcher Daniel Fiott for their thoughtful comments on an initial version of this article. 